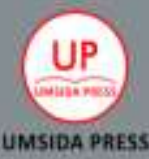

\title{
Sutarman
}

\section{MIKROBIOLOGI TANAH}

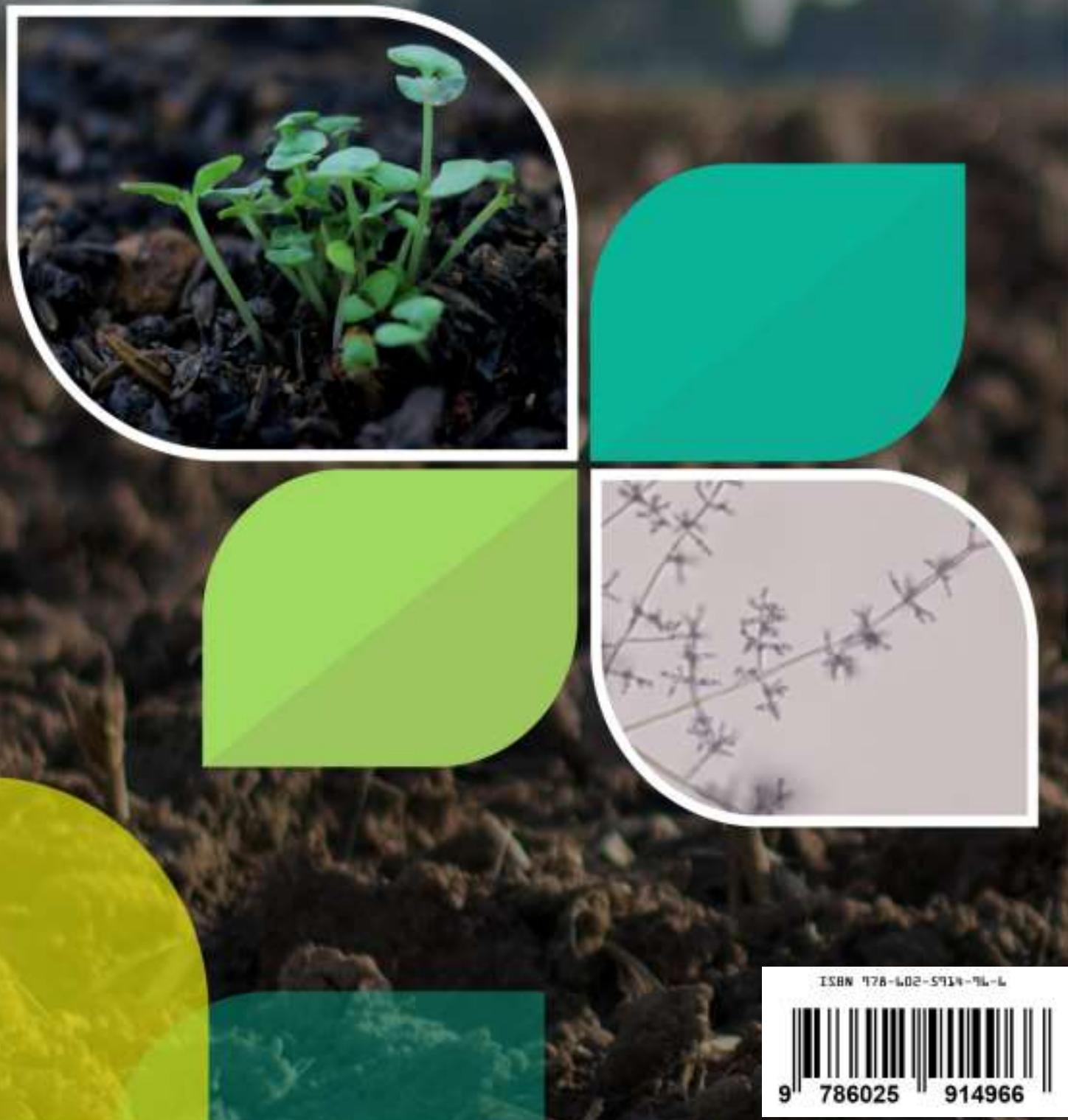




\title{
MIKROBIOLOGI TANAH
}

\author{
Oleh \\ Sutarman
}

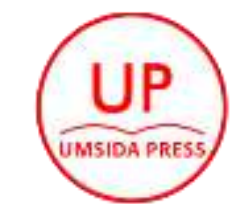

UMSIDA PRESS

Diterbitkan oleh

\section{UMSIDA PRESS}

J1. Mojopahit 666 B Sidoarjo

\section{ISBN:}

Copyright@2019

\section{Sutarman}

All rights reserved

Hak cipta dilindungi undang-undang.

Dilarang memperbanyak atau memindahkan sebagian atau seluruh isi buku ini ke dalam bentuk apapun, secara elektronis, maupun mekanis, termasuk fotokopi, merekam, atau dengan teknik perekaman lainnya, tanpa izin tertulis dari penerbit.

[Berdasarkan UU No. 19 Tahun 2000 tentang Hak Cipta Bab XII Ketentuan Pidana, Pasal 27, Ayat (1), (2), dan (6) 


\section{MIKROBIOLOGI TANAH}

\section{Penyusun}

\section{Sutarman}

Dosen Program Studi Agroteknologi

Fakultas Sains dan Teknologi, Universitas Muhammadiyah Sidoarjo

\section{Penerbit}

\section{UMSIDA PRESS}

(Anggota IKAPI No. 18/Anggota Luar Biasa/JTI/2019)

P3I Universitas Muhammadiyah Sidoarjo

Kampus 1 Universitas Muhamamdiyah Sidoarjo

Jl. Mojopahit 666 B Sidoarjo, Jawa Timur, Indonesia

Telp. +62 318945444

Fax +62 318949333

https://p3i.umsida.ac.id 


\section{KATA PENGANTAR}

Puji syukur kehadirat Allah SWT atas tersusunnya Bahan Ajar berjudul Mikrobiologi Tanah: Bagi Peningkatan Kesuburan Lahan Kering sebagaimana mestinya.

Buku ini disusun berdasarkan hasil kajian literatur yang bersumber pada berbagai artikel jurnal nasional dan Internasional relevan terkait serta merupakan salah satu luaran Hibah Kemenristekdikti dalam skema Penelitian Terapan Unggulan Perguruan Tinggi 2018-2019.

Buku selain dapat digunakan sebagai materi kuliah Kesuburan Tanah dan Pengelolaan Pupuk, juga dapat dimanfaatkan bagi bahan ajar mata kuliah Bioteknologi Pertanian mengingat di dalmnya terdapat Bab mengenai agensia biofertilizer dan agensia biokontrol serta bioteknologi tanah.

Pada kesempatan ini penulis menyampaikan terima kasih kepada: Rektor Universitas Muhammadiyah Sidoarjo (UMSIDA), Dekan Fakultas Sains dan Teknologi UMSIDA atas dukungan moril dan fasilitas yang disediakan bagi penyusunan buku ini.

Semoga karya ilmiah ini bermanfaat.

Sidoarjo, Agustus 2019

Penyusun 


\section{DAFTAR ISI}

\section{Halaman}

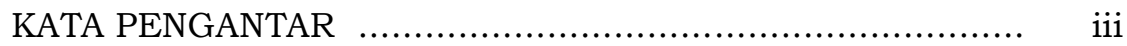

DAFTAR ISI …......................................................... iv

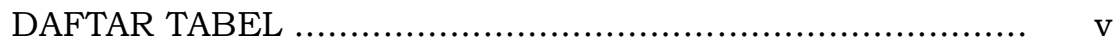

DAFTAR GAMBAR .................................................. vi

BAB 1. PENDAHULUAN ................................................ 1

1.1 Latar Belakang dan Lingkup ...................... 1

1.2 Kompetensi dan Capaian Pembelajaran ....... 8

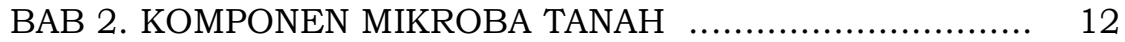

BAB 3. EKOLOGI ....................................................... 20

3.1 Ekologi Fungi ....................................... 20

3.2 Ekologi Bakteri .................................... 31

BAB 4. SITOLOGI DAN FISIOLOGI .............................. 35

4.1 Sitologi dan Perkembang Biakan ................ 35

4.1.1 Fungi ........................................ 35

4.1.2 Bakteri ......................................... 38

4.2 Fisiologi Mikroba Tanah ............................ 39

4.2.1 Fisiologi Fungi ............................. 41

4.2.2 Fisiologi Bakteri …....................... 49

BAB 5. FUNGI EFEKTIF …..................................... 53

4.1 Mikoriza ............................................... 53

4.2 Trichoderma ........................................... 60

4.3 Agen Biofertilizer Lain ............................. 61

4.4 Agen Biokontrol dan Fungi Efektif Lain ......... 65

BAB 6. BAKTERI EFEKTIF ........................................... 70

6.1 Bakteri Nodul Akar ........................................ 70

6.2 Bakteri Efektif Lain ................................... 74

BAB 7. APLIKASI BIOTEKNOLOGI TANAH $\ldots \ldots \ldots \ldots \ldots \ldots \ldots . . . . . . . . . .78$

7.1 Prinsip Apilkasi Bioteknologi Tanah .............. 78

7.2 Isolasi dan Formulasi Agensia Hayati ............ 80

7.3 Aplikasi Bioteknologi Tanah ........................ 84 


\section{DAFTAR TABEL}

Halaman

1. Kompetensi, capaian pembelajaran dan pokok bahasan Mikrobiologi Tanah

2. Karakteristik klas dan sub klas fungi

3. Karaketeristik tanah-tanaman-fungi mikoriza ericoid, ektomikoriza, dan endomikoriza 


\section{DAFTAR GAMBAR}

Halaman

1. Beberapa fungi tanah yang bermanfaat .......... 15

2. Analisis spesifisitas primer dengan menggunakan elektroforesis gel ..................... 17

3. Pohon filogenetika umum …......................... 18

4. Hubungan antara distribusi bioma sepanjang gradien lingkungan di lintang utara bumi dan peran asosiasi mikoriza dalam pengambilan $\mathrm{N}$ dan $\mathrm{P}$

5. Siklus hidup Saccaromycess $\quad$....................... 37

6. Siklus hidup Mucor ..................................... 37

7. Siklus hidup bakteri sebagai bentuk vegetatif yang membelah terus dan sebagai spora untuk bertahan

8. Penampilan akar bibit cengkeh tanpa mikoriza dan terinfeksi fungi ektomikoriza .................. 56

9. Spora fungi endomikoriza Glomus coronatum dan Glomus sp. ........................................

10. Tahapan proses nodulasi akar oleh bakteri bintil akar ..............................................

11. Diagram reaksi yang terjadi pada nodul akar selama fiksasi $\mathrm{N}$.......................................

12. Tahapan-tahapan metodologis atas proses menyeluruh penentuan aktivitas biomassa dan keragaman mikroba 


\section{BAB 1 \\ PENDAHULUAN}

\subsection{Latar Belakang dan Lingkup}

Mikroba tanah adalah komponen utama biota tanah dan sangat menentukan status kesuburan dan kesehatan tanah. Mikroba tanah dipelajari dalam dalam kajian Mikrobiologi Tanah (Soil Microbiology) yaitu ilmu yang mempelajari mikroorganisme tanah dan berbagai proses di dalamnya.

Banyak komponen biota tanah yang dipelajari dalam ilmu mikrobiologi tanah yaitu meliput: bakteri, fungi, protozoa, serta mikroflora dan mikrofauna lainnya dengan propagul mandiri terbesar memiliki ukuran di sekitar $10^{-4}$ $\mathrm{m}$ atau tidak lebih dari $100 \mu \mathrm{m}$ (milimikron). Dengan ukuran kurang dari 0,1 $\mathrm{mm}$, maka sulit mata manusia dapat melihat bentuk dan keberadaan jasad mikro ini. Propagul mandiri dimaksud yaitu individu tunggal bisa dalam bentuk spora satu sel misalnya fungi Aspergillus atau bentuk spora bersel banyak misalnya fungi Fusarium sp. bersel 3-4; sementara itu untuk potongan hifa fungi (sebagai propagul mandiri) berukuran diameter sekitar 2-4 $\mu \mathrm{m}$. Penggunaan mikroskop sebagai alat bantu dapat memperbesar ukuran obyek yang tampak di lensa okuler hingga 1.000 kali; sementara itu bagi pemula untuk melihat jasad nematoda Meloidogyne betina cukup dengan menggunakan lup pada perbesaran 10 kali. Struktur propagul berukuran besar bisa dilihat dengan mata yaitu 
terlihat seperti potongan benang kain, namun kita tidak bisa melihat komponen penyusun sesungguhnya yang merupakan miselium yang menyatu membentuk kumpulan atau agregat. Fungi mikoriza Scleroderma columnare yang bersiombiosis dengan akar Pinus merkusii akan tampak sebagai benang-benang putih di perakaran pinus sesungguhnya merupakan untaian hifa eksternal yang tumbuh dari akar secara masif membentuk kumpulan miselium di dalam tanah. Pada pertumbuhan simbiosis yang sempurna pada tanaman pinus tingkat tiang hingga pohon sering kali menghasilkan struktur seperti mushroom dan disebut tubuh buah (mengandung spora) yang muncul di permukaan tanah sekitar perakaran pohon pinus.

Dari sekian banyak jenis mikrob tanah relatif elum terlalu banyak jeni-jenis yang dikaji dan dikembangkan teknologi aplikasinya sebagai bioferilizer oleh para ilmuwan. Dari dunia bakteri sudah dikenal beberapa jenis Rhizobum, Azotobacter, Bacillus, Pseumonas dan banyak lainya yang dimanfaatkan sebagai biofertilizer. Sementara itu untuk dunia fungi setidaknya ada dua kelompok besar yaitu fungi Trichoderma dan fungi mikoriza. Potensi spesis Trichoderma sebagai agent biokontrol penyakit tanaman pertama kali ditemukan pada awal 1930an (Howell, 2003), dan saat ini lebih banyak dikenal dan diaplikasikan oleh petani dibandingkan dengan pemanfaatannya sebagai biofertilezer. Fungi mikoriza adalah fungi yang mampu bersimbiosis mutualistis dengan tumbuhan (terutama pada lahan kering). Fungi mikoriza arbuskula berkontribusi 
penting dalam menjaga kualitas dan produktivitas tanaman sekaligus menjamin terpenuhinya daya dukung lahan bagi pertanian berkelanjutan (Gianinazzi et al., 2010). Perannya membantu tanaman dalam penyerapan air dan nutrisi dari sumbernya yang seringkali tidak terjangkau bulu-bulu akar, membuatnya layak disebut sebagai agent bioferilizer.

Dua sarana penting yang digunakan dalam usaha tani yaitu pupuk dan pestisida tidak bisa dilepaskan dari keberhasilan produksi tanaman. Peningkatan produksi serelaia dari tahun 1960-2000 misalnya diikuti oleh peningkatan pemupukan $\mathrm{N}$ dan $\mathrm{P}$ serta peningkatan produksi dan import pestisida pada negara-negara penghasilnya. Praktek pertanian dapat mengurangi kemampuan ekosistem untuk menyediakan barang dan jasa. Aplikasi pupuk dan pestisida yang tinggi (Gbr. 1b, c) dapat meningkatkan nutrisi dan racun dalam air tanah dan badan air, menimbulkan biaya kesehatan dan pemurnian air, dan menurunkan hasil perikanan dan produktivitas tempat wisata, menurunkan kualitas tanah berkontribusi eutrofikasi habitat perairan, mengubah komposisi dan mengurangi keanekaragaman hayati dalam sistem nonpertanian, juga menurunkan kemampuan ekosistem untuk menyediakan beberapa layanan kepada kehidupan atau menurunkan daya dukungnya bagi kehidupan (Tilman et al., 2002).

Berbagai mikroba saat ini banyak dikembangkan sebagai agensi biofertilizer yang dapat berperan sebagai 
pupuk bagi kebutuhan tanaman. Kelebihan penggunaan mikroba sebagai biofertilizer adalah kemampuannya berkembang biak pada lingkungan yang sesuai sehingga tidak dperlukan perulagan aplikasi seperti halnya pada pemberian pupuk kimia.

Dua kelompok besar fungi yaitu Trichoderma dan mikoriza sudah dipahami sebagai kelompok utama fungi yang berperan besar di dalam upaya manusia untuk memperbaiki atau memulihkan kesuburan tanah dan daya dukung lahan bagi kegiatan budidaya. Meskipun sejak tahun 1990-an pemanfaatan fungi Trichoderma dan fungi Mikoriza sebagai bioferttilizer sudah dimulai, namun bioteknologi berbasis pemanfaatan kedua fungi ini masih terus berkembang secara progresif. Di luar aspek rekayasa genetika dalam pemanfaatan kedua fungi ini, kiranya berbagai riset yang bersifat menginventarisir, menyeleksi, dan menguji perannya sebagai bioferilizer serta penciptaan formulasi bagi kepentingan aplikasi yang kompatibel secara bioekologi dan pengembangan teknologi konservasinya masih merupakan ladang yang sangat luas untuk digarap baik oleh para peneliti (dosen dan mahasiswa) maupun para praktisi tidak saja di Indonesia tapi juga di seluruh dunia.

Salah satu kata kunci dalam pemanfaatan bakteri Bacillus, Pseudomonas, Azotobacter serta fungi Trichoderma dan Mikoriza adalah biofertlizer yang didefinisikan sebagai pupuk hayati.

Laporan tentang menurunnya kualitas lahan pertanian di Indonesia dibuktikan dengan makin tergantungnya lahan 
pada input bahan kimia yang mengancam daya dukung lingkungan bagi kelestarian produksi tanaman dan produktivitas lahan. Menurut Suriadikarta dan Simanungkalit (2006) sebagian besar lahan pertanian telah mengalami degradasi tingkat kesuburannya yang ditandai dengan kandungan $\mathrm{C}$ organik rata-rata di dalam tanah yang relative sangat rendah yaitu kurang dari $2 \%$. Penyebabnya adalah pencemaran oleh bahan kimia pupuk dan pestisida yang digunakan secara masif dalam rangka untuk memenuhi target produksi dan mencegah kegagalan panen akibat gangguan hama dan patogen serta gulma. Ketergantungan pada pestisida dan pupuk kimia mendorong peningkatan laju degradasi dari waktu ke waktu dengan konsekwensi terancamnya eksistensi mikroorganisme tanah sebagai agen pendukung kesuburan tanah dan kesehatan tanaman.

Berbagai penelitian di perguruan tinggi dan lemabaga penelitian yang fokus pada kesuburan tanah banyak diarahkan pada inventarisasi, isolasi, pengujian efektivitas dalam meningkatkan dan memulihkan kesuburan tanah, serta perbanyakan dan produksi masaal. Banyak hasil penelitian yang menunjukkan trend positif membantu memulihkan kesuburan tanah, namun banyak pula yang efektivitasnya diragukan ketika diaplikasikan ke lapangan. Balum bisa dipastikan sejauhmana pestisida dan pupuk kimia mempengaruhi potensi keragaan fungi soil borne dalam merehabilitasi kesuburan tanah. Namun berbagai upaya harus terus ditumbuh-kembangkan termasuk 
mengembangkan pencarian sumber plasmanutfah mikroba tanah efektif misalnya dengan menginventarisasi dan menguji isolat-solat miroba tanah termasuk dari kelompok bakteri efektif dan fungi efektif yang berasal dari lahan yang bukan diusahakan secara intensif bagi tanaman pertanian misalnya lahan hutan tanaman dan/atau lahan koservasi.

Keberhasilan pemulihan kesuburan tanah dan lahan pertanian berarti mengandung indikasi meningkatnya aktivitas mikroba tanah yang menguntungkan; hal ini pastilah sejalan dan/atau berbanding lurus dengan peningkatan rata-rata hasil dekomposisi bahan organik yang merupakan subtrat bagi berbagai biota tanah, dengan asumsi input bahan organik ke dalam tanah menjamin kebutuhan rata-rata mikroba tanah. Peningkatan kesuburan tanah secara biologi sudah tentu akan meningkatkan kesuburan secara kimia dan fisika tanah. Aktivitas mikroba yang optimal akan saling terkait dengan peningkatan total hasil dekomposisi bahan organik dan pada gilirannya akan meningkatkan status nutrisi di dalam tanah baik unsur-unsur makro, mikroa, dan trace element.

Level optimal kesuburuan tanah yang pulih atau meningkat dari kondisi yang miskin akan menjamin kualitas lahan secara keseluruhan, mengingat tiap tanaman dan/atau tumbuhan yang hidup di lahan yang diusahakan akan memberikan kontribusi bagi jaminan keberlangsungan hidup yang optimal bagi biota tanah. Dalam kondisi ini siklus hara yang baik akan terjaga dan rantai makanan dalam ekosistem di lahan tersebut akan 
terpelihara dengan baik pula. Kondisi ini sudah tentu akan memberikan jaminan bagi kelestarian daya dukung lahan bagi upaya membangun ketahanan pangan masyarakat.

Marjinalisasi lahan sebagai akibat mismanagement dalam penerapan agroteknologi sudah tentu akan memarjinalkan masyarakat yang tinggal di desa pertanian dan/atau di desa pinggiran hutan yang sebagian besar sesungguhnya sangat tergantung pada kesuburan tanah. Kemiskinan terstruktur yang terjadi dalam masyarakat pedesaan ini tentunya akan semakin menggeser kemampuan kita dalam pencapai peningkatan kesejahteraan, maka jika berlangsung lama bukan saja akan menimbukkan krisis pangan dan krisis ekonomi, tapi juga berakibat terjadinya krisis sosial dan krisis kepercayaan kepada pemerintah dan kaum elit termasuk para ilmuwan di perguruan tinggi.

Untuk mencegah sumber ancaman ketahaan pangan yang dapat dipersempit mencegah degradasi lahan, maka pengembangan riset dan implementasi teknologi biofertilizer mutlak dilakukan. Penelitian dan pengembangan potensi agent pupuk hayati bagi beberapa mikroba tanah, terutama dan konteks ini adalah fungi Trichoderma dan fungi Mikoriza sangat mulak diperlukan.

\subsection{Kompetensi dan Capaian Pembelajaran}

\section{Materi Perkuliahan}

Adapun materi perkuliahan yang terdistrusi dalam tiap minggu selama satu semester adalah meliputi: 
1. Lingkup Mikrobiologi Tanah

2 Komponen Mikroba Tanah

3 Bioekologi

4 Sitologi dan Fisiologi

5 Fungi tanah

6. Bakteri Tanah

7. Aplikasi Bioteknologi Tanah

\section{Kompetensi dan Capaian Pembelajaran}

Kompetensi dan capaian pembelajaran Mikrobilogi Tanah dengan masing-masing pokok dan sub pokok pembahasannya disajikan pada Tabel 1 .

Tabel 1. Kompetensi, capaian pembelajaran dan pokok bahasan Mikrobiologi Tanah

\begin{tabular}{|l|l|l|l|}
\hline No & $\begin{array}{c}\text { Kompetensi } \\
\text { Dasar }\end{array}$ & \multicolumn{1}{|c|}{$\begin{array}{c}\text { Capaian } \\
\text { Pembelajaran }\end{array}$} & \multicolumn{1}{|c|}{$\begin{array}{c}\text { Pokok } \\
\text { Bahasan }\end{array}$} \\
\hline 1 & $\begin{array}{l}\text { Mahasiswa } \\
\text { memahami } \\
\text { lingkup dan } \\
\text { pentingnya }\end{array}$ & $\begin{array}{l}\text { Mahasiswa mampu } \\
\text { menerangkan } \\
\text { batasan, lingkup, } \\
\text { dan mandap } \\
\text { Mikrobiologi Tanah }\end{array}$ & $\begin{array}{l}\text { Mikrobiologi } \\
\text { Tanah }\end{array}$ \\
\hline
\end{tabular}




\begin{tabular}{|c|c|c|c|}
\hline & $\begin{array}{l}\text { Mikrobiologi } \\
\text { Tanah }\end{array}$ & & \\
\hline 2 & $\begin{array}{l}\text { Mahasiswa } \\
\text { memahami } \\
\text { komponen } \\
\text { mikroba } \\
\text { penting tanah } \\
\text { bagi bidang } \\
\text { pertanian }\end{array}$ & $\begin{array}{l}\text { Mahasiswa dapat } \\
\text { menyebutkan dan } \\
\text { menjelaskan ciri-ciri } \\
\text { umum fungi dan } \\
\text { bakteri penting bagi } \\
\text { bidang budidaya } \\
\text { pertanian }\end{array}$ & $\begin{array}{l}\text { Kompoen } \\
\text { mikroba } \\
\text { tanah }\end{array}$ \\
\hline 3 & $\begin{array}{l}\text { Mahasiswa } \\
\text { memahami } \\
\text { dan mampu } \\
\text { menjelaskan } \\
\text { secara umum } \\
\text { ekologi } \\
\text { mikroba } \\
\text { penting tanah }\end{array}$ & $\begin{array}{l}\text { Mahasiswa dapat } \\
\text { menjelaskan ekologi } \\
\text { secara fungi dan } \\
\text { bakteri umum serta } \\
\text { asosiasi dan } \\
\text { simbiosis di rhizosfer } \\
\text { fungi dan bakteri } \\
\text { penting tanah bagi } \\
\text { budidaya pertanian }\end{array}$ & $\begin{array}{l}\text { Bioekologi } \\
\text { mikroba }\end{array}$ \\
\hline 4 & $\begin{array}{l}\text { Mahasiswa } \\
\text { memahami } \\
\text { dan mampu } \\
\text { menjelaskan } \\
\text { secara umum } \\
\text { sitologi dan } \\
\text { fisiologi } \\
\text { mikroba } \\
\text { penting tanah }\end{array}$ & $\begin{array}{l}\text { Mahasiswa dapat } \\
\text { menjelaskan sitologi } \\
\text { dan } \\
\text { perkembangbiakan } \\
\text { termasuk fisiologi } \\
\text { fungi dan bakteri } \\
\text { penting tanah bagi } \\
\text { budidaya pertanian }\end{array}$ & $\begin{array}{ll}\text { Sitologi } & \text { dan } \\
\text { Fisiologi } & \end{array}$ \\
\hline
\end{tabular}

Tabel 1. Kompetensi, capaian pembelajaran dan pokok bahasan Mikrobiologi Tanah (lanjutan)

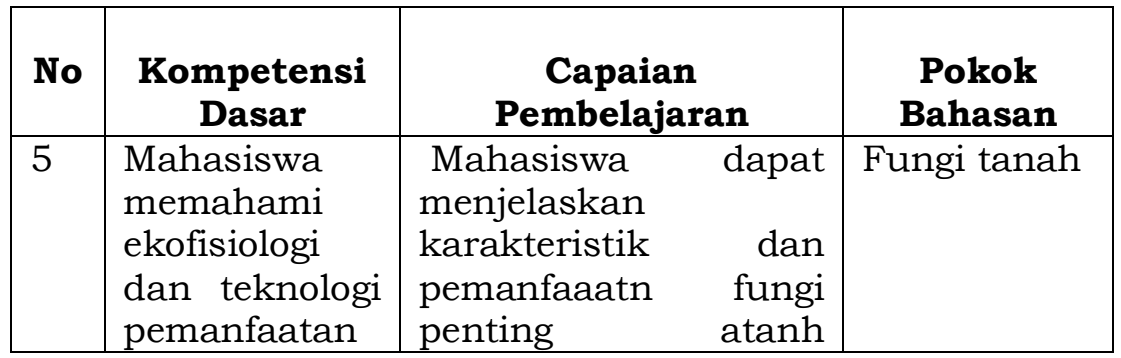




\begin{tabular}{|c|c|c|c|}
\hline & $\begin{array}{l}\text { mikoriza dan } \\
\text { fungi } \\
\text { potensial } \\
\text { tanah } \\
\text { pertanian }\end{array}$ & $\begin{array}{lr}\text { meliputi; } & \text { fungi } \\
\text { mikoriza, trichoderma, } \\
\text { dan fungi efektif } \\
\text { lainnya } \\
\text { mendukung } \\
\text { pertumbuhan } \\
\text { tanaman }\end{array}$ & \\
\hline 6 & $\begin{array}{l}\text { Mahasiswa } \\
\text { memahami } \\
\text { karakteristik } \\
\text { dan } \\
\text { pemanfaatan } \\
\text { bakteri } \\
\text { biofertilizer } \\
\text { dan agensia } \\
\text { pendukung } \\
\text { pertumbuhan } \\
\text { tanaman }\end{array}$ & $\begin{array}{lr}\text { Mahasiswa } & \text { dapat } \\
\text { menjelaskan } & \\
\text { karakteristik dan } & \text { dakteri } \\
\text { pemanfaaatn } & \text { bakting atanh } \\
\text { penting } & \text { meliputi; bakteri bintil } \\
\text { akar, agensi } & \text { biofertilizer, ran } \\
\text { bakteriefektif lainya } \\
\text { yang mendukung } \\
\text { pertumbuhan } \\
\text { tanaman }\end{array}$ & $\begin{array}{l}\text { Bakteri } \\
\text { tanah }\end{array}$ \\
\hline 7 & $\begin{array}{l}\text { Mahasiswa } \\
\text { memahami } \\
\text { aplikasi } \\
\text { bioteknologi } \\
\text { yang } \\
\text { memanfaatka } \\
\text { n mikroba } \\
\text { penitng } \\
\text { tanah bagi } \\
\text { budidaya } \\
\text { pertanian }\end{array}$ & $\begin{array}{l}\text { Mahasiswa dapat } \\
\text { menjelaskan prinsip } \\
\text { aplikasi bioteknologi } \\
\text { tanah serta mampu } \\
\text { mengaplikasikannya } \\
\text { dalam mendukung } \\
\text { pertumbuhan dan } \\
\text { kesehatan tanaman } \\
\text { budidaya pertanian }\end{array}$ & $\begin{array}{l}\text { Aplikasi } \\
\text { Bioteknologi } \\
\text { Tanah }\end{array}$ \\
\hline
\end{tabular}

\section{PERTANYAAN}

1. Kajian mikrobiologi tanah (soil microbiology) sangat pentng bagi pengembangan bioteknologi tanah, Mengapa? Jelaskan!

2. Dalam konteks degradasi lahan yang ditunjukkan oleh kandungan bahan organik tanah yang rendah, sejauh mana peran mata kuliah Mikrobiologi Tanah 
bagi mengatasi masalah ancaman degradasi lahan? Jelaskan!

3. Mengapa praktek pertanian saat ini mengancam kesuburan dan daya dukung lahan?

\section{DAFTAR PUSTAKA}

AlAskar AA \& Rashad YM. 2010. Arbuscular mycorrhizal fungi: a biocontrol agent against common bean Fusarium root rot disease. Plant Pathol. J. 9, 31-38.

Alguacil MM, Torrecillas E, García-Orenes F \& Roldán A. 2014. Changes in the composition and diversity of AMF communities mediated by management practices 
in a Mediterranean soil are related with increases in soil biological activity. Soil Biol. Biochem. 76, 34-44.

Al-Taweil HI, Osman MB, Aidil AH \& Wan-Yussof WM. 2009. Optimizing of Trichoderma viride cultivation in submerged state fermentation. Am. J. Appl. Sci. 6, 1277-1281.

Altieri MA \& Nicholis C.I. 2005. Agroecology and the Search for a Truly Sustainable Agriculture. Mexico. United Nations Environments Programme.

Bai C, He X, Tang H, Shan B \& Zhao L. 2009. Spatial distribution of arbuscular mycorrhizal fungi, glomalin and soil enzymes under the canopy of Astragalus adsurgens Pall. in the Mu Us sandland, China. Soil Biol. Biochem. 41, 941-947.

Barea JM, Palenzuela J, Cornejo P, Sánchez-Castro I, Navarro-Fernández C, Lopéz-García A, Estrada B, Azcón R, Ferrol N. \& Azcón-Aguilar C. 2011. Ecological and functional roles of mycorrhizas in semi-arid ecosystems of Southeast Spain. J. Arid Environ. 75, 1292-1301.

Bedini S, Avio L, Argese E \& Giovannetti M. 2007. Effects of long-term land use on arbuscular mycorrhizal fungi and glomalin-related soil protein. Agric. Ecosyst. Environ. 120, 463-466.

Benítez T, Rincón AM, Limón MC \& Codon A. 2004. Biocontrol mechanisms of Trichoderma strains. Int. Microbiol. 7 (4), 249-260.

Buysens C, César V, Ferrais F, De Boulois HD \& Declerck S.

2016. Inoculation of Medicago sativa cover crop with Rhizophagus irregularis and Trichoderma harzianum increases the yield of subsequently-grown potato under low nutrient conditions. Applied Soil Ecology 105, 137-143.

Camenzind T, Homeier J, Dietrich K, Hempel S, Hertel D, Krohn A, Leuschner C, Oelmann Y, Olsson PA, Suarez JP \& Rillig MC. 2016. Opposing effects of nitrogen 
versus phosphorus additions on mycorrhizal fungal abundance along an elevational gradient in tropical montane forests. Soil Biology \& Biochemistry 94, 3747.

Cavallazzi JRP, Filho OK, Stürmer SL, Rygiewicz PT \& de Mendonça MM. 2007. Screening and selecting arbuscular mycorrhizal fungi for inoculating micropropagated apple rootstocks in acid soils. Plant Cell Tissue Organ Cult. 90, 117-129. doi:http://dx.doi.org/10.1007/s11240-006-9163-6.

Chowdappa P, Kumar SPM, Lakshmi MJ \& Upreti KK. 2013. Growth stimulation and induction of systemic resistance in tomato against early and late blight by Bacillus subtilis OTPB1 or Trichoderma harzianum OTPB3. Biol. Control 65, 109-117.

Dix NJ \& Webster J. 1995. Fungal ecology. Chapman \& Hall. London.

Driver JD, Holben WE \& Rillig MC. 2005. Characterization of glomalin as a hyphal wall component of arbuscular mycorrhizal fungi. Soil Biol. Biochem. 37, 101-106.

Dubey SC, Suresha M, \& Singha B. 2007. Evaluation of Trichoderma species against Fusarium oxysporum $\mathrm{f}$. sp. ciceris for integrated management of chickpea wilt. Biol. Control 40, 118-127

Dwidjoseputro D. 2005. Dasar-dasar mikrobiologi. Jambatan. Jakarta.

Foyer CH \& Noctor G. 2004. Photosynthetic nitrogen assimilation and associated carbon and respiratory metabolism. Kluwer Academic Publisher. London.

Geisseler D \& Horwath WR. 2009. Relationship between carbon and nitrogen availability and extracellular enzyme activities in soil. Pedobiologia 53, 87-98.

Gerbore J, Benhamou N, Vallance J, Le Floch G, Grizard D, Regnault-Roger, C \& Rey P. 2014. Biological control of plant pathogens: advantages and limitations seen 
through the case study of Pythium oligandrum. Environ. Sci. Pollut. Res. Int. 21, 4847-4860.

Gianinazzi S, Gollotte A, Binet MN, van Tuinen D, Redecker

D \& Wipf D. 2010. Agroecology: the key role of arbuscular mycorrhizas in ecosystem services. Mycorrhiza 20, 519-530.

Gravel V, Antoun H \& Tweddell RJ. 2007. Growth stimulation and fruit yield improvement of greenhouse tomato plants by inoculation with Pseudomonas putida or Trichoderma atroviride: possible role of indole acetic acid (IAA). Soil Biol. Biochem. 39, 1968-1977.

Griffin DH. 1994. Fungal physiology. 2nd ed. Willey-Liss, Inc. New York.

Harman GE. 2006. Overview of mechanisms and uses of Trichoderma spp. Phytopathology 96, 190-194.

Heinemeyer A, Hartley IP, Evans SP, Carreira De La Fuente JA \& Ineson P. 2007. Forest soil CO2 flux: uncovering the contribution and environmental responses of ectomycorrhizas. Glob. Change Biol. 13, 1786-1797. doi:http://dx.doi.org/10.1111/j.13652486.2007.01383.x.

Howell CR. 2003. Mechanisms employed by Trichoderma species in the biological control of plant diseases: the history and evolution of current concepts. Plant Dis. $87,4-10$

Hu X, Roberts DP, Xie L, Yu C, Li Y, Qin L, Hu L, Zhang Y, \& Liao X. 2016. Use of formulated Trichoderma sp. Tri1 in combination with reducedrates of chemical pesticide for control of Sclerotinia sclerotiorium on oilseed rape. Crop Protection 79, 124-127.

Jindapunnapat K, Chinnasri B \& Kwankuae S. 2013. Biological control of Root-knot nematodes (Meloidogyne enterolobii) in guava by the fungus Trichoderma harzianum. J. Dev. Sustainable Agric. 8, 110-118. 
Kuzyakov Y \& Larionova AA. 2005. Root and rhizomicrobial respiration: a review of approaches to estimate respiration by autotrophic and heterotrophic organisms in soil. J. Plant Nutr. Soil Sci. 168, 503-520. doi:http://dx.doi.org/10.1002/jpln.200421703.

Legaya N, Grassein F, Binet MN, Arnoldi C, Personeni E, Perigon S, Polyd F, Pommier T, Puissant J, Clément JC, Lavorel S \& Mouhamadou B. 2016. Plant species identities and fertilization influence on arbuscular mycorrhizal fungal colonisation and soil bacterial activities. Applied Soil Ecology 98, 132-139.

Lichtfouse, E. 2010. Sustainable Agriculture Reviews 3. Sociology, Organic Farming, Climate Change, and Soil Science. Netherlands. Springer.

Lievens, B., Brouwer, M., Vanachter, A.C.R.C., Cammue, B.P.A., Thomma, B.P.H.J., 2006. Real-time PCR for detection and quantification of fungal and oomycete tomato pathogens in plant and soil samples. Plants Sci. $171,155-165$.

Martinson GO, Corre MD \& Veldkamp E. 2013. Responses of nitrous oxide fluxes and soil nitrogen cycling to nutrient additions in montane forests along an elevation gradient in southern Ecuador. Biogeochemistry 112, 625-636.

Moyano F, Kutsch W \& Schulze E. 2007. Response of mycorrhizal, rhizosphere and soil basal respiration to temperature and photosynthesis in a barley field. Soil Biol. Biochem. 39, 843-853. doi:http://dx.doi.org/10.1016/j.soilbio.2006.10.001.

Noortasiah, 2005. Pemanfaatan Bakteri Rhizobium pada tanaman kedelai di lahan lebak. Buletin Teknik Pertanian, 10 (2): 57-60.

Nottingham AT, Turner BL, Winter K, van der Heijden MGA \& Tanner EVJ. 2010. Arbuscular mycorrhizal mycelial respiration in a moist tropical forest. New Phytol. 186, 
957-967. doi:http://dx.doi.org/10.1111/j.14698137.2010.03226.x.

Paul EA \& Clarck FE. 1996. Soil microbiology and biochemistry 2nd ed. Academic Press. San Diego.

Pruksakorna P, Araia M, Kotokua N, Vilchèze C,. Baughn AD, Moodley P, Jacobs WR Jr. \& Kobayashia M. 2010. Trichoderins, novel aminolipopeptides from a marine sponge-derived Trichoderma sp., are active against dormant mycobacteria. Bioorganic \& Medicinal Chemistry Letters 20 (12): 3658-3663

Purwaningsih, S. 2005. Rhizobium dari tanah kebun biologi Wamena. Biodiversitas. 6(2): 82-84.

Read D \& Perez-Moreno J. 2003. Mycorrhizas and nutrient cycling in ecosystems - a journey towards relevance? New Phytologist 157, 475-492.

Richardson A, Lynch J, Ryan P, Delhaize E, Smith FA, Smith SE, Harvey $P$, Ryan $M$, Venklaas $E$, Lambers $H$, Oberson A, Culvenor R \& Simpson R. 2011. Plant and microbial strategies to improve the phosphorus efficiency of agriculture. Plant and Soil 349, 121-156.

Rillig MC, Wright SF, Nichols KA, Schmidt WF \& Torn MS. 2001. Large contribution of arbuscular mycorrhizal fungi to soil carbon pools in tropical forest soils. Plant Soil 233, 167-177.

Sahebani N \& Hadavi N. 2008. Biological control of the rootknot nematode Meloidogyne javanica by Trichoderma harzianum. Soil Biol. Biochem. 40, 2016-2020.

Samuels GJ. 2006. Trichoderma: Systematics, the Sexual State, and Ecology. Phytopathology 96 (2): 195-206.

Shanmugaiah V, Balasubramanian N, Gomathinayagam S, Monoharan PT \& Rajendran A. 2009. Effect of single application of Trichoderma viride and Pseudomonas fluorences on growth promotion in cotton plants. Afr. J. Agric. Res. 4, 1220-1225. 
Saravanakumar K, Yu C, Dou K, Wang M, Li Y \& Chen J. 2016. Synergistic effect of Trichoderma-derived antifungal metabolites and cell wall degrading enzymes on enhanced biocontrol of Fusarium oxysporum f. sp. cucumerinum. Biological Control 94 (2016) 37-46.

Singh B, Kaur R \& Singh K. 2008. Characterization of Rhizobium strain isolated from the roots of Trigonella foenumgraecum (fenugreek). African Journal of Biotechnology. 7 (20): 3671- 3676.

Six J, Elliott ET \& Paustian K. 2000. Soil macroaggregate turnover and microaggregate formation: a mechanism for $\mathrm{C}$ sequestration under no-tillage agriculture. Soil Biol. Biochem. 32, 2099-2103.

Smith SE \& Smith FA. 2011. Roles of arbuscular mycorrhizas in plant nutrition and growth: new paradigms from cellular to ecosystem scales. Annual Review of Plant Biology 62, 227-250.

Srivastava R., Khalid A, Singh US \& Sharma AK. 2010. Evaluation of arbuscular mycorrhizal fungus, fluorescent Pseudomonas and Trichoderma harzianum formulation against Fusarium oxysporum f. sp. lycopersici for the management of tomato wilt. Biological Control 55, 24-31.

Steinberg PD \& Rillig MC. 2003. Differential decomposition of arbuscular mycorrhizal fungal hyphae and glomalin. Soil Biol. Biochem. 35, 191-194.

Sullivan, P. 2003. Applying the Principles of Sustainable Farming. Fundamental of Sustainable Agriculture. ATTRA.

Suriadikarta DA \& Simanungkalit RDM. 2006. Pendahuluan. In: Simanungkalit RDM, Suriadikarta DA, Saraswati R, Setyorini D \& Hartatik W (eds.). Pupuk organic dan pupuk hayati. Pp. 1-10. Balai Besar Litbang Sumberdaya Lahan Pertanian, Badan Penelitian dan Pengembangan Pertanian. Bogor. 
Sutarman. 1997. Effect of compost to intensity of mychorryzal infection on the roots of Pinus merkusii. $J$. Agritek 5 (2): 79-90.

Sutarman, S. Hadi, A. Suryani, Achmad, \& A. Saefuddin. 2004. Patogenesis hawar daun bibit Pinus merkusii yang disebabkan oleh Pestalotia theae di pesemaian. J. Hama dan Penyakit Tumbuhan Tropika 4(1): 32-41.

Sutarman \& Prihartiningrum AE. 2015. Penyakit hawar daun Pinus merkusii di berbagai persemaian kawasan utama hutan pinus Jawa Timur. J. HPT Tropika 15 (1): 44-52.

Teste FP, Lalibert E, Lambers H, Auer Y, Kramer S \& Kandeler E. 2016. Mycorrhizal fungal biomass and scavenging declines in phosphorus impoverished soils during ecosystem retrogression. Soil Biology \& Biochemistry 92, 119-132.

Tilman D, Cassman KG, Matson PA, Naylor R \& Polasky S. 2002. Agricultural sustainability and intensive production practices. Nature 418, 671-677.

Tomè E, Tagliavini M \& Scandellari F. 2015. Recently fixed carbon allocation in strawberry plants and concurrent inorganic nitrogen uptake through arbuscular mycorrhizal fungi. J. Plant Physiol. 179, 83-89. doi:http://dx.doi.org/10.1016/j.jplph.2015.02.008.

Van der Heijden MG, Streitwolf-Engel R, Riedl R, Siegrist S, Neudecker A, Ineichen K, Boller T, Wiemken A \& Sanders IR. 2006. The mycorrhizal contribution to plant productivity, plant nutrition and soil structure in experimental grassland. New Phytologist 172, 739752.

Verma M, Brar SK, Tyagi RD, Surampalli RY \& Valero JR. 2007. Antagonistic fungi, Trichoderma spp.: panoply of biological control. Biochemistry Engineering Journal $37,1-20$.

Vinale F, Sivasithamparam K, Ghisalberti EL, Marra R, Barbetti MJ, Li H, Woo SL \& Lorito M. 2008. A novel 
role for Trichoderma secondary metabolites in the interactions with plants. Physiol. Mol. Plant Pathol. 72, 80-86.

Voets L, De Boulois HD, Renard L, Strullu DG \& Declerck S. 2005. Development of an autotrophic culture system for the in vitro mycorrhization of potato plantlets. FEMS Microbiol. Lett. 248, 111-118.

Wang B \& Qiu YL. 2006. Phylogenetic distribution and evolution of mycorrhizas in land plants. Mycorrhiza 16, 299-363.

Werner D \& Newton WE. 2005. Nitrogen fixation in agriculture, forestry, ecology and the environment. Springer. Netherlands.

Widyati E., Irianto R.S.B., Santosa S., Najmullah, \& Sutarman. 2001. The impact of carbofuran environmental insecticide against fungi ectomychorryzal Pisolithus arrhizus and Schleroderma columnare inoculated on seedlings of Pinus merkusii Jung et de Vries. J. Agritek 9 (3): 1178-1182.

Yedidiaa I, Benhamoub N, Kapulnikc Y \& Cheta I. 2000. Induction and accumulation of PR proteins activityduring early stages of root colonizationby the mycoparasite Trichoderma harzianum strain T-203. Plant Physiology and Biochemistry 38 (11): 863-873.

Youssef SA, Tartoura KA \& Abdelraouf GA. 2016. Evaluation of Trichoderma harzianum and Serratia proteamaculans effect on disease suppression, stimulation of ROS-scavenging enzymes and improving tomato growth infected by Rhizoctonia solani. Biological Control 100, 79-86. 